\title{
REVIEW PAPER ON SEISMIC RESPONSES OF MULTISTORED RCC BUILDING WITH MASS IRREGULARITY
}

\author{
Sagar R Padol ${ }^{1}$, Rajashekhar S. Talikoti ${ }^{2}$ \\ ${ }^{1} P G$ Student, Late G. N. Sapkal College of Engineering,Nashik,Maharashtra, India \\ ${ }^{2}$ Head of Department, Late G. N. Sapkal College of Engineering, Nashik, Maharashtra, India
}

\begin{abstract}
From past earthquakes it is proved that many of structure are totally or partially damaged due to earthquake. So, it is necessary to determine seismic responses of such buildings. There are different techniques of seismic analysis of structure. Time history analysis is one of the important techniques for structural seismic analysis generally the evaluated structural response is nonlinear in nature. For such type of analysis, a representative earthquake time history is required. In this project work seismic analysis of RCC buildings with mass irregularity at different floor level are carried out. Here for analysis different time histories have been used. This paper highlights the effect of mass irregularity on different floor in RCC buildings with time history and analysis is done by using ETABS software.
\end{abstract}

Keywords: Seismic Analysis, Time History Analysis, Base Shear, Storey Shear, Story Displacement.

\section{INTRODUCTION}

During an earthquake, failure of structure starts at points of weakness. Generally weakness is due to geometry, mass discontinuity and stiffness of structure. The structures having this discontinuity are termed as Irregular structures. These structures contain a large portion of urban infrastructure. Hence structures fail during earthquakes due to vertical irregularity.

According to IS 1893:

The irregularity in the building structures may be due to irregular distributions in their mass, strength and stiffness along the height of building. When this type of building are constructed in high intensity zones, the design and analysis of structure becomes complicated. There are two types of irregularities-

1. Plan Irregularities.

2. Vertical Irregularities.

Vertical Irregularities are of five types-

a) Stiffness Irregularity - Soft Storey-A soft storey is one in which the lateral stiffness is less than 70 percent of the storey above or less than 80 percent of the average lateral stiffness of the three storey's above.

b) Stiffness Irregularity - Extreme Soft Storey-An extreme soft storey is one in which the lateral stiffness is less than 60 percent of that in the storey above or less than 70 percent of the average stiffness of the three storey's above.

ii) Mass Irregularity-Mass irregularity shall be considered to exist where the seismic weight of any storey is more than 200 percent of that of its adjacent storey's. In case of roofs irregularity need not be considered.

iii) Vertical Geometric Irregularity- A structure is considered to be Vertical geometric irregular when the horizontal dimension of the lateral force resisting system in any storey is more than 150 percent of that in its adjacent storey.
Buildings are designed as per Design based earthquake, but the actual forces acting on the structure is more than the design earthquake. So, in higher seismic zones Ductility based design approach is preferred as ductility of the structure narrows the gap. The primary objective in designing an earthquake resistant structure is to ensure that the building has enough ductility to withstand the earthquake load.

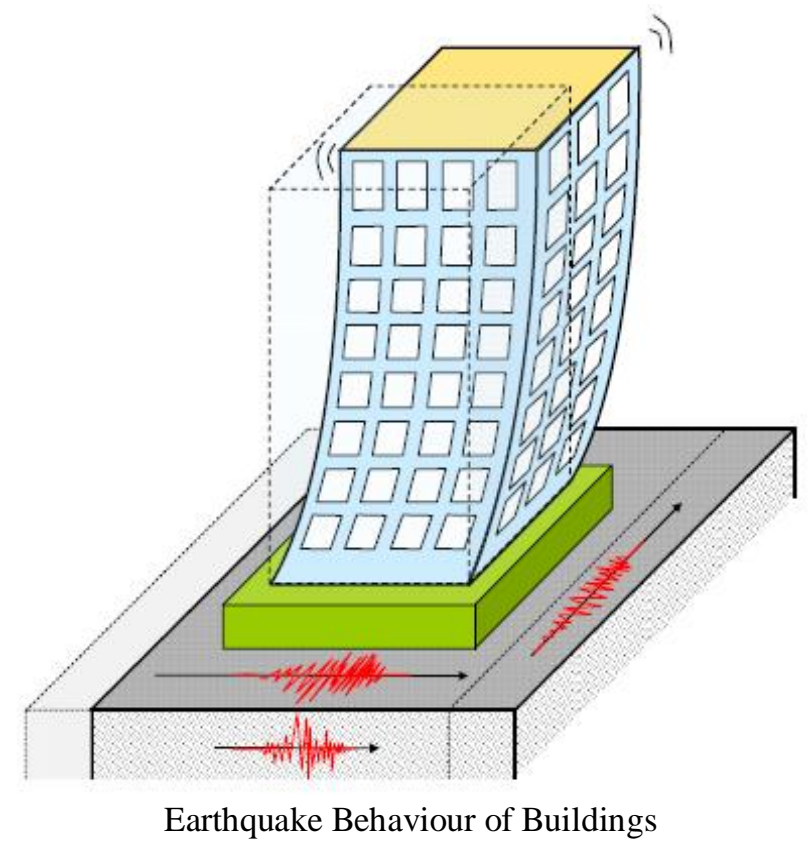

2. LITERATURE REVIEW

Seismic analysis is a major tool in earthquake engineering which is used to understand the response of buildings due to seismic excitations in a simpler manner. In the past the buildings were designed just for gravity loads and seismic 
analysis is a recent development. It is a part of structural analysis and a part of structural design where earthquake is prevalent.

Mayuri D. Bhagwat et.al [1] In this work dynamic analysis of G+12 multistoried practiced RCC building considering for Koyna and Bhuj earthquake is carried out by time history analysis and response spectrum analysis and seismic responses of such building are comparatively studied and modeled with the help of ETABS software. Two time histories (i.e. Koyna and Bhuj) have been used to develop different acceptable criteria (base shear, storey displacement, storey drifts).

Himanshu Bansal et al [2] In this study the storey shear force was found to be maximum for the first storey and it decreased to a minimum in the top storey in all cases. It was found that mass irregular building frames experience larger base shear than similar regular building frames. The stiffness irregular building experienced lesser base shear and has larger inter storey drifts.

Mohit Sharma et al [3] In this study a G+30 storied regular building. The static and dynamic analysis has done on computer with the help of STAAD-Pro software using the parameters for the design as per the IS-1893- 2002-Part-1 for the zones- 2 and 3.

A. B. M. Saiful Islam et al [4] In this study analyses results show that isolation system considerably reduce earthquake induced load on building. Furthermore, method of analysis has been found to have considerable effect on the response of low to medium rise buildings. Time history analysis shows significant less base shear than that from response spectrum analysis. Also, less isolator displacement is obtained from time history analysis than that from response spectrum analysis.

A S Patil et al [5] This study shows similar variations pattern in Seismic responses such as base shear and storey displacements with intensities $\mathrm{V}$ to $\mathrm{X}$. From the study it is recommended that analysis of multistoried RCC building using Time History method becomes necessary to ensure safety against earthquake force.

Md. Arman Chowdhury et al [6] In this study regular and irregular and irregular building with and without isolator are analyse. Installation of isolator in buildings which increases the time period of the structure and due to this it reduces the possibility of resonance of the structure. By providing isolator in building the cost increases, but reinforcement requirement and material cost is reduced

P. P. Chandurkar et al [7] In this study shear walls, is considered as major earthquake resisting member. Structural wall gives an effective bracing system and offer good potential for lateral load resistance. So it is important to determine the seismic response of the wall or shear wall. In this study main focus is to determine the location for the shear wall in multi storey building.
Prof. S.S. Patil et al [8] This study gives seismic analysis of high rise building using program in STAAD Pro. with considering different conditions of the lateral stiffness system. Analysis is carried out by response spectrum method. This analysis gives the effect of higher modes of vibration and actual distribution of force in elastic range in good way. These results include base shear, storey drift and storey deflection are presented.

\section{METHODOLOGY}

If the structure not properly designed and constructed with required quality they may cause large destruction of structures due to earthquakes. Time history analysis is an useful technique for seismic analysis of structure when the structure shows nonlinear response. This method is step by step analysis of the seismic responses of a structure to a specified loading that may change with time.

1) Extensive literature survey by referring books, technical papers carried out to understand basic concept of topic.

2) Selection of type of structures.

3) Modeling of the selected structures

4) Analytical work is to be carried out.

5) Interpretation of result and conclusion.

In the present work it is proposed to carry out seismic analysis of multistored RCC buildings using time history analysis method considering mass irregularity at different floor levels with the help of ETABS software.

\section{CONCLUSION}

Many of the studies have shown seismic analysis of the RCC structures with different irregularities such as mass irregularity, stiffness and vertical geometry irregularity. Whenever a structure having different irregularity, it is necessary to analyse the building in various earthquake zones. From many past studies it is clear that effect of earthquake on structure can be minimize by providing shear wall, base isolation etc.

\section{REFERENCES}

[1] Mayuri D. Bhagwat, Dr.P.S.Patil, "Comparative Study of Performance of Rcc Multistory Building For Koyna and Bhuj Earthquakes" ,International Journal of Advanced Technology in Engineering and Science www.ijates.com Volume No.02, Issue No. 07, July 2014 ISSN (online): 2348 - 7550.

[2] Himanshu Bansal, Gagandeep, "Seismic Analysis and Design of Vertically Irregular RC Building Frames" International Journal of Science and Research (IJSR) ISSN (Online): 2319-7064, Impact Factor (2012): 3.358

[3] Mohit Sharma, Dr. Savita Maru, “ Dynamic Analysis of Multistoried Regular Building" IOSR Journal of Mechanical and Civil Engineering (IOSR-JMCE) eISSN: 2278-1684,p-ISSN: 2320-334X, Volume 11, Issue 1 Ver. II (Jan. 2014), PP 37-42 www.iosrjournals.org 
[4] A. B. M. Saiful Islam*, Mohammed Jameel and Mohd Zamin Jummat, "Study on optimal isolation system and dynamic structural responses in multistorey buildings" International Journal of the Physical Sciences Vol. 6(9), pp. 2219-2228, 4 May, 2011 Available online at http://www.academicjournals.org/IJPS DOI: 10.5897/IJPS10.441 ISSN 1992 - 1950 C2011 Academic Journals.

[5] A S Patil and P D Kumbhar, "Time History Analysis of MultistoriedRcc Buildings For Different Seismic Intensities “ ISSN 2319 - 6009 www.ijscer.com Vol. 2, No. 3, August 2013 (C) 2013 IJSCER.

[6] Md. Arman Chowdhury, Wahid Hassan, "Comparative study of the Dynamic Analysis of Multi-storey Irregular building with or without Base Isolator" International Journal of Scientific Engineering and Technology (ISSN : 2277-1581) Volume No.2, Issue No.9, pp : 909-912 1 Sept. 2013.

[7] ] P. P. Chandurkar, Dr. P. S. Pajgade, “ Seismic Analysis of RCC Building with and Without Shear Wall" International Journal of Modern Engineering Research (IJMER) www.ijmer.com Vol. 3, Issue. 3, May - June 2013 pp-1805-1810 ISSN: 2249-6645.

[8] Prof. S.S. Patil, ,Miss. S.A. Ghadge, ,Prof. C.G. Konapure, , Prof. Mrs. C.A. Ghadge. " Seismic Analysis of High-Rise Building by Response Spectrum Method" International Journal Of Computational Engineering Research (Ijceronline.Com) Vol. 3 Issue. 3

\section{BIOGRAPHIES}

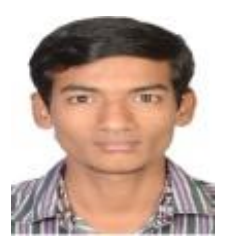

Sagar Ramesh Padol, PG Student, Late G. N. Sapkal College of Engineering Nashik, Maharashtra, India

E-mail: padolsagar@gmail.com

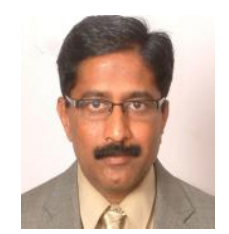

Dr. Rajashekhar S. Talikoti, Head of Department, Late G. N. Sapkal College of Engineering, Nashik, Maharashtra, India E-mail: rstalikoti@gmail.com 